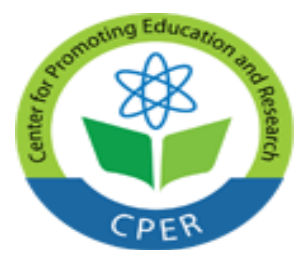

\title{
EFFECT OF DISCIPLINE AND MOTIVATION TO ORGANIZATIONAL PERFORMANCE THROUGH ORGANIZATIONAL COMMITMENT PT. INDO PREMIER SECURITIES
}

\author{
Wahyu Sosiawan \\ Student Master of Management \\ Universitas Krisnadwipayana Jakarta \\ Indonesia \\ Abdul Rivai \\ Associate Professor \\ Faculty of Economics \\ Universitas Krisnadwipayana Jakarta \\ Indonesia

\section{Dr. Iwan Kurniawan Subagja} \\ Lecturer \\ Faculty of Economics \\ Universitas Krisnadwipayana Jakarta \\ Indonesia
}

\section{Abstract}

This study aimed to determine the effect of discipline and motivation to organizational performance, determine the effect of discipline and motivation on organizational commitment, the effect of organizational commitment on organizational performance, and determine the effect of discipline and motivation to organizational performance through organizational commitment.The study was conducted on the organization of PT. Indo Premier Securities. Sampling using saturated samples involving 70 employees in all parts of the organization. Analysis of data using path analysis. The results showed that the variables of discipline and motivation affect organizational performance. The discipline and motivation variable influence on organizational commitment. Organizational commitment variables effect on organizational performance. Variables affecting the role of organizational commitment to discipline and motivation affect organizational performance.

\section{Keywords: discipline, motivation, organizational commitment, organizational performance}

\section{Introduction}

Performance of the organization according to the concept of PBM SIG (the performance-based management special interest group is to perform monitoring and reporting programs and pay attention to objectives achieved. Performance is measured based on the activities of the program yagn run, products, and services produced. Organizational performance should be measured not only in terms of financial concepts but also of non-financial. Performance can be measured by productivity, quality, and consistency and so on. on the other hand organizational performance measure results, levels of behavioural and normative, educational and concepts generated including development management (Richard, 2010).

One of the factors that affect organizational performance is the discipline of employees. Discipline is a condition for correcting or punishing employees who violate the provisions or procedures established the organization. A discipline is a form of control that the implementations of employee jobs are always in the corridor 


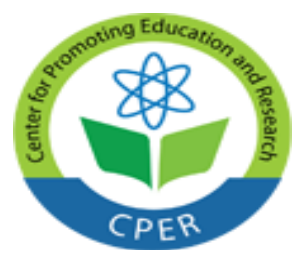

VOL: 5, ISSUE: 2

February/2019

E-ISSN: 2469-6501

(c) Center for Promoting Education and Research (CPER) USA

WWW.cpernet.org

regulations and legislation in force. Sinambela (2012: 242) describes the aims applied a disciplined approach with the hope that the truth has not been on the stage of punishment, but rather coaching. In essence, the discipline is obedience to rules or orders established by the organization. In this case, the discipline is a process used to deal permasatahan performance; this process involves managers in identifying and communicating problems to the employee's performance. Synthesis Discipline is the organization's efforts to move the employees in accordance with the applicable rules of the organization with the purpose of their adherence to employee well.

Another factor affecting organizational performance is motivation. Motivation interpreted also as a force that drives the power source and controls human behavior. Motivation as an effort to encourage a person to take the desired action, while the motif as a propulsive force someone to do. The term motivation comes from the Latin is movere which means moving or moving. Because a person's behavior tends to be goal-oriented and driven by the desire to achieve a particular goal.

Motivation is the willingness of individuals to issue a high effort to achieve organizational goals (Robbins, 2014). In a work context, motivation is one important factor in encouraging an employee to work. There are three key elements in the motivation that effort, the organization's goals, and needs.

Therefore, it takes the intensity and quality of those efforts and focused on organizational goals. The effort is a measure of intensity. When someone motivated then he will strive mightily to achieve the goals, but not necessarily a high effort will produce high karyawanyang performance. Necessity is the internal conditions conducive to the stimulation, wherein unsatisfied needs will cause a voltage that stimulates the urge from within the individual.

Organizational commitment is also expected to affect organizational performance. According to Robbins and Judge (2008:100) organizational commitment is a condition in which an employee favouring certain organizations as well as the goals and desires to retain membership in the organization. Thus, a high job involvement means favouring certain work of an individual, while a high organizational commitment means favouring organizations that recruit such individuals.

Meanwhile, according to Moorhead and Griffin (2013: 73) organizational commitment is an attitude that reflects the extent to which an individual to know and adhere to the organization. An individual who has committed is likely to see himself as a true member of the organization. Meanwhile, according to Kreitner and Kinicki (2014: $165)$ that reflects the organization's commitment to recognizing the degree to which someone tied to an organization and its goals.

It can be concluded that organizational commitment is a psychological state of individuals associated with faith, trust and a strong reception to the goals and values of the organization, a strong willingness to work for the organization and the degree to which someone still wants to be a member of the organization.

\section{Literature Review \\ Organizational Performance}

According to Richard et al (2010), organizational performance is generated by organizations that include results (outcomes) that the financial performance such as profit, as measured by return on assets, returns on investment and so on, the performance of the market such as the expansion of market shares, and sales. Besides the return of shareholders a return of shareholders and increase the economy of shareholders.

In some areas of the organization's performance can also be measured by other things such as strategic planning, operations, and finance, legal and organizational development. In developing the institution or organization is a necessity to survive in the competitive world climate. 


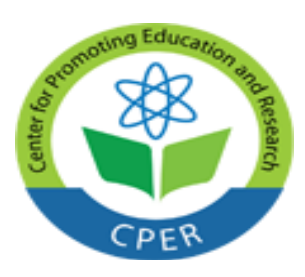

The purpose of productivity associated with the development of that organization (Shrestha, 2014). Small organizations that have a desire to continue to grow and become large. The growing organization in order mengkomadi development itself.

\section{Discipline}

According to Fatony dan Rizki (2013) describes the sense of discipline viewed from the perspective of resource management mansia, are: Discipline is the sixth operative functions of Human Resource Management. Discipline is the operative function of Human Resource Management is most important because the better the discipline of employees, the higher the performance it achieves.

Fathoni said discipline is an important operative function for the higher discipline of an employee, the higher also his performance. While Davis (in Mangkunegera, 2008:129) argues that "discipline is management action to enforce the standards organization," meaning that the discipline can be defined as the implementation of management to reinforce the organization's guidelines.

Furthermore, Sedarmayanti (2013: 381) argues discipline is a condition for correcting or punishing employees who violate the provisions or procedures established the organization. Discipline is a form of control that the implementations of employee jobs are always in the corridor regulations and legislation in force.

\section{Motivation}

Motivation interpreted also as a force that drives the power source and controls human behavior. Motivation as an effort to encourage a person to take the desired action, while the motif as a propulsive force someone to do. The term motivation comes from the Latin is movers which means moving or moving. Because a person's behavior tends to be goal-oriented and driven by the desire to achieve a particular goal.

Motivation is the willingness of individuals to issue a high effort to achieve organizational goals (Robbins, 2008). In a work context, motivation is one important factor in encouraging an employee to work. There are three key elements in the motivation that effort, the organization's goals, and needs.

Therefore, it takes the intensity and quality of those efforts and focused on organizational goals. The effort is a measure of intensity. When someone motivated then he will strive mightily to achieve the goals, but not necessarily a high effort will produce high karyawanyang performance. Necessity is the internal conditions conducive to the stimulation, wherein unsatisfied needs will cause a voltage that stimulates the urge from within the individual.

Basically, motivated employees are in a state of tension and seek to reduce tensions by issuing effort. This raises the impetus search behavior to find a purpose, certain. If it turns out occurs fulfilment, there will be a reduction in the voltage.

With the proper motivation of the employees will be encouraged to do as much as possible in carrying out their duties because they believed that the organization's success in achieving goals and targets, the personal interests of the members of the organization will be covered as well. With high motivation will create a commitment to what they are responsible for completing each job (McNeese-Smith et al, 1993).

\section{Organizational Commitment}

According to Robbins and Judge (2008: 100) organizational commitment is a condition in which an employee favouring certain organizations as well as the goals and desires to retain membership in the organization. Thus, a high job involvement means favouring certain work of an individual, while a high organizational commitment means favouring organizations that recruit such individuals. 


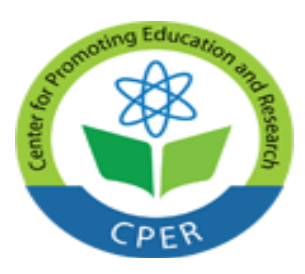

VOL: 5, ISSUE: 2

February/2019

https://ijbassnet.com/

E-ISSN: 2469-6501

(C) Center for Promoting Education and Research (CPER) USA

WWW.cpernet.org

Meanwhile, according to Moorhead and Griffin (2013: 73) organizational commitment is an attitude that reflects the extent to which an individual to know and adhere to the organization. An individual who has committed is likely to see himself as a true member of the organization. Meanwhile, according to Kreitner and Kinicki (2014:165) that reflects the organization's commitment to recognizing the degree to which someone tied to an organization and its goals.

It can be concluded that organizational commitment is a psychological state of individuals associated with faith, trust and a strong reception to the goals and values of the organization, a strong willingness to work for the organization and the degree to which it still wants to be a member of the organization.

\section{Research Methods}

\section{Research Design}

This research uses explanatory analysis approach. This means that each of the variables presented in the hypothesis will be observed by testing the causal relationship of independent variables on the dependent variable.

That phenomenon can be designed through the following mathematical functions:

\section{Model 1 (one)}

Simultaneously influence between X1 (discipline) and X2 (motivation) to variable Y (organizational performance) can be formulated by: $\mathrm{Y}=\mathrm{f}(\mathrm{X} 1, \mathrm{X} 2)$

2. Model 2 (two)

The influence of the independent variables X1 (discipline) to Performance (Y) can be formulated with: X3 = $f\left(X_{1}\right)$

\section{Model 3 (three)}

Partial effect between X2 (motivation) to Performance (Y) can be formulated with: $Y=f\left(X_{2}\right)$

4. Model 4 (four)

Partial effect between organizational commitment variable (X3) to Y (organizational performance) can be formulated with: $Y=\mathrm{f}(\mathrm{X} 3)$

\section{Model 5 (five)}

Partial effect between X1 (discipline) to $\mathrm{Y}$ (organizational performance) through variable organizational commitment $(\mathrm{X} 3)$ can be formulated with:

$$
\begin{aligned}
& \mathrm{X} 3=\mathrm{f}(\mathrm{X} 1) \\
& Y=\mathrm{f}(\mathrm{X} 3)
\end{aligned}
$$

\section{Model 6 (six)}

Partial effect between X2 (motivation) to $\mathrm{Y}$ (organizational performance) through variable organizational commitment $(\mathrm{X} 3)$ can be formulated with:

\section{Object of Research}

$$
\begin{aligned}
& \mathrm{X} 3=\mathrm{f}(\mathrm{X} 2) \\
& Y=\mathrm{f}(\mathrm{X} 3)
\end{aligned}
$$

The study was conducted at PT Indo Premier Securities; Indo Premier Securities head office is located at Wisma GKBI 7th Floor Suite 718, Jl. Jend.Sudirman No. 28 -Jakarta 10210 - Indonesia. 


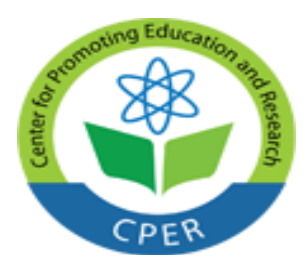

VOL: 5, ISSUE: 2

February/2019

https://ijbassnet.com/

E-ISSN: 2469-6501

CCenter for Promoting Education and Research (CPER) USA

WWW.cpernet.org

\section{Population and Sample Research}

The population is a generalization region consisting of the objects/subjects that have a certain quantity and characteristics defined by the researchers to learn and then drawn conclusions (Sugiyono,2014). Samples were towing the majority of the population to represent the entire population, (Surakhmad, 2001).

The population used in this study is the number of employees the company is as many as 70 people. The number of samples taken entirely. This sampling is referred to as a saturated sample is sampling done entirely from the population.

\section{Results and Discussion}

1. Discipline and Motivation Influence on Organizational Performance

Linear analysis model can be based on calculations using SPSS program as follows.

Table 1. Results of Analysis First Equation

\begin{tabular}{|c|c|c|c|c|c|}
\hline \multirow[b]{2}{*}{ Model } & \multicolumn{2}{|c|}{$\begin{array}{c}\text { Unstandardized } \\
\text { Coefficients }\end{array}$} & \multirow{2}{*}{$\begin{array}{c}\text { Standardized } \\
\text { Coefficients } \\
\text { beta }\end{array}$} & \multirow[b]{2}{*}{$\mathrm{t}$} & \multirow[b]{2}{*}{ Sig. } \\
\hline & $B$ & Std. Error & & & \\
\hline 1 (Constant) & 16.208 & 2,926 & & 5.539 &, 000 \\
\hline DISCIPLINE & , 719 &, 131 & , 438 & 5.466 &, 000 \\
\hline MOTIVATION &, 578 &, 082 &, 562 & 7.019 &, 000 \\
\hline
\end{tabular}

a. Dependent Variable: PERFORMANCE

Equation: $Y=0,438 \times 1+0,562 \times 2$

Table 2. The value of the F-count

\begin{tabular}{|ll|r|r|r|r|l|}
\hline \multicolumn{2}{|l|}{ Model } & Sum of & & & & \\
\hline 1 & Squares & df & mean Square & F & Sig. \\
& Regression & 1410.670 & 2 & 705.335 & 46.039 &, $000 \mathrm{~b}$ \\
& Residual & 1026.473 & 67 & 15.320 & & \\
& Total & 2437.143 & 69 & & & \\
\hline
\end{tabular}

a. Dependent Variable: PERFORMANCE

b. Predictors: (Constant), Motivation, Discipline

Based on Table 2, it is known that the value of f-count equal to 46.039 and significance of 0.00 . This value is less than 0.05. This means discipline and motivation variables affect organizational performance.

Table 3. Rated R Squares Regression Model First

\begin{tabular}{|l|l|r|r|r|r|}
\hline $\begin{array}{l}\text { Mode } \\
\text { I }\end{array}$ & R & R Square & $\begin{array}{l}\text { Adjusted R } \\
\text { Square }\end{array}$ & $\begin{array}{c}\text { Std. Error of the } \\
\text { Estimate }\end{array}$ & Durbin-Watson \\
\hline 1 &, $761 \mathrm{a}$ &, 579 &, 566 & 3.91414 & 1.222 \\
\hline
\end{tabular}

a. Predictors: (Constant), Motivation, Discipline

b. Dependent Variable: PERFORMANCE

Based on Table 3, it is known that the value of $\mathrm{r}$ squared of $57.9 \%$ means discipline and motivation variable influence on organizational performance by $57.9 \%$ while the rest influenced by other variables that are not incorporated into the model equations. 


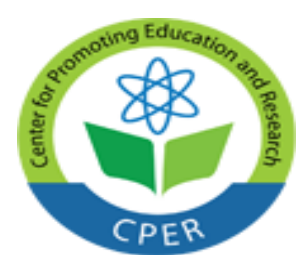

VOL: 5, ISSUE: 2

February/2019

https://ijbassnet.com/

E-ISSN: 2469-6501

(C) Center for Promoting Education and Research (CPER) USA

\section{Influence of Discipline to Organizational Performance}

Table 4. Results of regression equation analysis Second

\begin{tabular}{|c|c|c|c|c|c|c|}
\hline \multirow{2}{*}{\multicolumn{2}{|c|}{ Model }} & \multicolumn{2}{|c|}{$\begin{array}{c}\text { Unstandardized } \\
\text { Coefficients }\end{array}$} & \multirow{2}{*}{$\begin{array}{c}\begin{array}{c}\text { Standardized } \\
\text { Coefficients }\end{array} \\
\text { beta }\end{array}$} & \multirow[b]{2}{*}{$t$} & \multirow[b]{2}{*}{ Sig. } \\
\hline & & B & Std. Error & & & \\
\hline \multirow[t]{2}{*}{1} & (Constant) & 26.044 & 3,359 & & 7.753 &, 000 \\
\hline & $\begin{array}{l}\text { DISCIPLIN } \\
\text { E }\end{array}$ &, 851 &, 170 &, 519 & 5.004 &, 000 \\
\hline
\end{tabular}

a. Dependent Variable: PERFORMANCE

Equation: $Y=0,519 \times 1$

Based on Table 4, the results of the above analysis discipline known that the coefficient of 0.519 . $\mathrm{T}$ value of 5.004. The significant value of 0.00 . The significance value smaller than 0.05 . This means that the discipline variables affect organizational performance.

Table 5. The value of $r$ Quadratic Equations Second

\begin{tabular}{|l|r|r|r|r|}
\hline Model & $\mathrm{R}$ & R Square & Adjusted R Square & $\begin{array}{c}\text { Std. Error of the } \\
\text { Estimate }\end{array}$ \\
\hline 1 &, $519 \mathrm{a}$ &, 269 &, 258 & 5.11811 \\
\hline
\end{tabular}

a. Predictors: (Constant), DISCIPLINE

Based on Table 5, it can be seen $r$ squared value of 0.269 . This means discipline variables influence on the performance of $26.9 \%$ and the rest influenced by other variables not included in the model equations.

\section{Effect of Motivation on Organizational Performance}

Table 6. Analysis Third Regression Equations

\begin{tabular}{|c|c|c|c|c|c|}
\hline \multirow[b]{2}{*}{ Model } & \multicolumn{2}{|c|}{$\begin{array}{c}\text { Unstandardized } \\
\text { Coefficients }\end{array}$} & \multirow{2}{*}{$\begin{array}{c}\text { Standardized } \\
\text { Coefficients } \\
\text { beta }\end{array}$} & \multirow[b]{2}{*}{$\mathrm{t}$} & \multirow[b]{2}{*}{ Sig. } \\
\hline & B & Std. Error & & & \\
\hline 1 (Constant) & 28.769 & 2,162 & & 13.307 &, 000 \\
\hline MOTIVATION &, 642 &, 097 &, 625 & 6,608 &, 000 \\
\hline
\end{tabular}

a. Dependent Variable: PERFORMANCE

Equation: $Y=0,625 \times 2$

Based on the chart above analysis it is known that motivation coefficient of 0.625 . T value of 6,608 . The significant value of 0.00 . The significance value smaller than 0.05 . This means that the motivation variable influence on organizational performance.

Table 7. Value Quadratic Equations r Third

\begin{tabular}{|l|r|r|r|r|}
\hline Model & $\mathrm{R}$ & R Square & Adjusted R Square & $\begin{array}{c}\text { Std. Error of the } \\
\text { Estimate }\end{array}$ \\
\hline 1 &, $625 \mathrm{a}$ &, 391 &, 382 & 4.67176 \\
\hline
\end{tabular}

a. Predictors: (Constant), MOTIVATION

Based on Table 7, it can be seen $r$ squared value of 0.391 . This means that the motivation variable influence on organizational performance of $39.1 \%$ and the rest influenced by other variables not included in the model equations. 


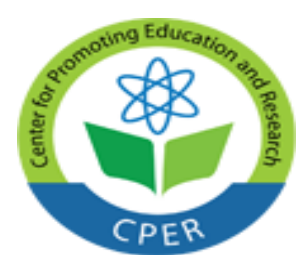

VOL: 5, ISSUE: 2

February/2019

https://ijbassnet.com/

E-ISSN: 2469-6501

CCenter for Promoting Education and Research (CPER) USA

WWW.cpernet.org

4. Influence of Organizational Commitment to Organizational Performance

Table 8. Results of regression equation analysis Fourth

\begin{tabular}{|c|c|c|c|c|c|c|}
\hline \multirow{2}{*}{\multicolumn{2}{|c|}{ Model }} & \multicolumn{2}{|c|}{$\begin{array}{c}\text { Unstandardized } \\
\text { Coefficients }\end{array}$} & \multirow{2}{*}{$\begin{array}{c}\text { Standardized } \\
\text { Coefficients }\end{array}$} & \multirow[b]{2}{*}{$\mathrm{t}$} & \multirow[b]{2}{*}{ Sig. } \\
\hline & & $B$ & Std. Error & & & \\
\hline 1 & (Constant) & 8.884 & 2.469 & \multirow[b]{2}{*}{858} & 3.599 & .001 \\
\hline & $\begin{array}{l}\text { COMMITM } \\
\text { ENT }\end{array}$ & , 807 &, 058 & & $\begin{array}{r}13,80 \\
0\end{array}$ &, 000 \\
\hline
\end{tabular}

a. Dependent Variable: PERFORMANCE

Equation: $Y=0,859 \times 3$

Based on the chart above analysis it is known that the coefficient of organizational commitment at 0.859 . $\mathrm{T}$ value of 13.8. The significant value of 0.00 . The significance value smaller than 0.05 . This means that the organizational commitment variables affect organizational performance.

Table 9. Value Quadratic Equations r Fourth

\begin{tabular}{|l|r|r|r|r|}
\hline Model & $\mathrm{R}$ & R Square & Adjusted R Square & Std. Error of the Estimate \\
\hline 1 &, $858 \mathrm{a}$ &, 737 &, 733 & 3.07090 \\
\hline
\end{tabular}

a. Predictors: (Constant), COMMITMENT

Based on Table 9, it can be seen $r$ squared value of 0.737 . This means that the effect of variable working commitment to organizational performance amounted to $73.7 \%$ and the rest influenced by other variables not included in the model equations.

5. Influence of Discipline on Organizational Performance through Organizational Commitment

Table 10. Influence of Organizational Commitment Against Discipline

\begin{tabular}{|c|c|c|c|c|c|c|}
\hline \multirow{2}{*}{\multicolumn{2}{|c|}{ Model }} & \multicolumn{2}{|c|}{ Unstandardized Coefficients } & \multirow{2}{*}{$\frac{\text { Standardized Coefficients }}{\text { beta }}$} & \multirow[b]{2}{*}{$\mathrm{t}$} & \multirow[b]{2}{*}{ Sig. } \\
\hline & & B & Std. Error & & & \\
\hline \multirow[t]{2}{*}{1} & (Constant) & 19.916 & 3.197 & & 6.229 & 000 \\
\hline & DISCIPLINE & 1,124 &, 162 & 644 & 6.943 & 000 \\
\hline
\end{tabular}

a. Dependent Variable: COMMITMENT

That the influence of discipline to organizational performance is 0.519 . Disciplinary influence on organizational performance through commitment is $0.644 \times 0.858=0.552$. In this case the indirect effect is greater than the direct effect so that it can be said that the variables of organizational commitment as an intervening variable.

6. Effect of Motivation on Organizational Performance through Organizational Commitment

Table 11. Coefficient Values Influence Motivation on Organizational Commitment

\begin{tabular}{|c|c|c|c|c|c|}
\hline \multirow[b]{2}{*}{ Model } & \multicolumn{2}{|c|}{ Unstandardized Coefficients } & \multirow{2}{*}{$\begin{array}{c}\text { Standardized Coefficients } \\
\text { beta }\end{array}$} & \multirow[b]{2}{*}{$\mathrm{t}$} & \multirow[b]{2}{*}{ Sig. } \\
\hline & $B$ & Std. Error & & & \\
\hline (Constant) & 23.492 & 1,854 & & 12.673 & 000 \\
\hline MOTIVATION & , 849 & 083 &, 777 & 10.191 & 000 \\
\hline
\end{tabular}

a. Dependent Variable: COMMITMENT

Based on the image above it can be seen that the direct effect of motivation on organizational performance is 0.625. While the influence of motivation on organizational performance through the commitment of work 


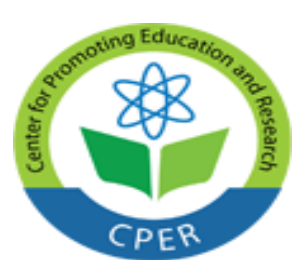

organization is $0.777 \times 0.858=0.667$. In this case smaller than the direct influence indirect influence so we can say that the variables of organizational commitment as an intervening variable.

\section{Conclusions and Recommendations \\ Conclusion}

Discipline and motivation variables affect organizational performance. F-value calculated at 46.039 and significance of 0.00 . This value is less than 0.05 . R squared value of $57.9 \%$ means discipline and motivation variable influence on organizational performance by $57.9 \%$ while the rest influenced by other variables that are not incorporated into the model equations.

Discipline variables affect organizational performance. T value of 5.004. The significant value of 0.00 . The significance value smaller than 0.05 . R squared value of 0.269 . This means discipline variables influence the performance of $26.9 \%$ and the rest influenced by other variables not included in the model equations.

Motivational variables affect organizational performance. T value of 6,608. The significant value of 0.00 . The significance value smaller than 0.05 . $\mathrm{R}$ squared value of 0.391 . This means that the motivation variable influence on the organizational performance of $39.1 \%$ and the rest influenced by other variables not included in the model equations.

Organizational commitment variables affect organizational performance. $\mathrm{T}$ value of 13.8. The significant value of 0.00 . The significance value smaller than 0.05 . $\mathrm{R}$ squared value of 0.737 . This means that the effect of variable organizational commitment to organizational performance amounted to $73.7 \%$ and the rest influenced by other variables not included in the model equations.

Disciplinary influence on organizational performance is 0.519 . Disciplinary influence on performance through organizational commitment is $0.644 \times 0.858=0.552$. In this case, the indirect effect is greater than the direct effect so that it can be said that the variables of organizational commitment as an intervening variable.

The direct effect on the performance of organizational discipline is 0.625 . While the disciplinary effect on organizational performance through organizational commitment is $0.777 \times 0.858=0.667$. In this case smaller than the direct influence indirect influence so we can say that the variables of organizational commitment as an intervening variable.

\section{Recommendations}

Organizational performance needs to be improved by increasing discipline, motivation and commitment of employees. Increased discipline is also necessary to adhere to the rules, working on time and care to the rules has been made.

In improving organizational performance also needs to be improved motivation. This is done by taking into account the needs of employees as the amount of earned income, non-financial welfare and so on.

Organizational commitment also needs to be improved by increasing affective commitment, normative, and on-going commitment. Increasing this commitment made by familiarizing employees to understand the vision and mission understand the importance of seriousness in the work and understands the importance of maintaining and developing the organization in the future.

\section{References}

Allen, NJ., Meyer PJ. And Smith CA. (1993). "Commitment to Organizations and Occupations : Extension and Test of a Three-Component Conceptualization”, Journal of Applied Psychology, Vol. 78, No. 4.

Daft, Richard L. (2010). Manajemen . Edisi Kelima Jilid Satu. Jakarta : Erlangga. 


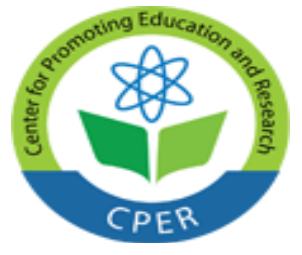

VOL: 5, ISSUE: 2

February/2019

https://ijbassnet.com/

E-ISSN: 2469-6501

(C) Center for Promoting Education and Research (CPER) USA

WWW.cpernet.org

Fatony dan Rizki. 2013. Pengaruh komitmen profesional terhadap kepuasan kerja (studi survey pada beberapa kantor akuntan publik di Bandung). http://repository.widyatama.ac.id

Kreitner \& Kinicki, (2015). Organizational Behavior . 8 th Edition . Boston : McGraw-Hill.

Mangkunegara. A.A. Prabu. Anwar. (2008). Evaluasi Kinerja Sumber Daya Manusia. Penerbit Refika Aditama. Bandung.

Moorhead, Gregory dan Ricky W. Griffin. (2013). Perilaku Organisasi. Jakarta: Salemba Empat.

Robbins, S. (2008). Perilaku Organisasi. Jilid 1 dan 2. Terjemahan oleh Hadyana Puja Atmaja. Jakarta: Prenhallindo.

Robbins, Stephen P., Coulter, Mary. (2014). Manajemen, Twelfth Edition. United States: Pearson Education Limited.

Sedarmayanti. (2013). Manajemen Sumber Daya Manusia, Reformasi Birokrasi Manajemen Pegawai Negeri Sipil. Rafika Aditama, Bandung.

Shrestha, S., \& Jose, P. (2014). Knowledge and practice of nursing ethics and laws. Journal of Universal Collage of Medical Sciences, Vol 02/No.03.

Sinambela, Lijan. (2012). Kinerja Pegawai: Teori, Pengukuran dan Implikasi. Yogyakarta: Graha Ilmu.

Sugiyono. (2014). Metode Penelitian Kuantitatif, Kualitatif, dan Kombinasi (Mixed Methods). Bandung : Alfabeta.

Winarno Surakhmad. (2001). Pengantar Penelitian Ilmiah Dasar Metode Teknik. Bandung: Tarsito. 